\title{
Occurrence of Vanadium in Belgian and European Alluvial Soils
}

\author{
V. Cappuyns and E. Slabbinck \\ Center for Economics and Corporate Sustainability, Hogeschool-Universiteit Brussel, Stormstraat 2, 1000 Brussels, Belgium \\ Correspondence should be addressed to V. Cappuyns, valerie.cappuyns@hubrussel.be
}

Received 16 November 2011; Accepted 23 January 2012

Academic Editor: Larissa Macedo dos Santos

Copyright () 2012 V. Cappuyns and E. Slabbinck. This is an open access article distributed under the Creative Commons Attribution License, which permits unrestricted use, distribution, and reproduction in any medium, provided the original work is properly cited.

\begin{abstract}
Vanadium $(\mathrm{V})$ is a naturally occurring trace element, but total concentrations in soils and sediments are also dependent on the parent material and might be influenced by anthropogenic activities (e.g., steel industry). Despite the fact that threshold values for $\mathrm{V}$ in soils and/or sediments exist in various European countries, in Belgium, $\mathrm{V}$ is not taken into account when the environmental quality of soils and sediments has to be evaluated, despite the existence of several (diffuse) sources for V. In the first part of the study, the occurrence of $\mathrm{V}$ alluvial soils in Belgium was compared with V concentrations in alluvial soils (floodplain soils) across Europe. By analysis of both the Belgian and European data, the relationship between physicochemical soil characteristics and total $\mathrm{V}$ concentrations was quantified and some areas polluted with $\mathrm{V}$ were detected. A regression equation, in which $\mathrm{V}$ concentrations in alluvial soils were expressed as a function of major element composition, was proposed for the Belgian and European data. Additionally, single extractions with $\mathrm{CaCl}_{2}\left(0.01 \mathrm{~mol} \mathrm{~L}^{-1}\right)$ and ammonium-EDTA $\left(0.05 \mathrm{~mol} \mathrm{~L}^{-1}\right)$ were used to estimate short- and long-term mobility of $\mathrm{V}$ in the alluvial soils.
\end{abstract}

\section{Introduction}

1.1. Vanadium in Soils and Sediments. Vanadium (V) naturally occurs as trace element in soils and sediments. The average concentration in soil is estimated to be around $150 \mu \mathrm{g} \mathrm{g}^{-1}$ [1] and $90 \mu \mathrm{gg}^{-1}$ [2]. The concentration of $\mathrm{V}$ in soils and sediments also depends on the parent material and the occurrence of $\mathrm{V}$-containing ore minerals in the subsoil [3]. Vanadium concentrations in igneous rocks are higher than in acidic and in siliceous rocks, whereas the $\mathrm{V}$ content of metamorphic and sedimentary rocks is intermediate between the content of basic and acidic igneous rocks [3]. In soils, $\mathrm{V}$ is mainly associated with $\mathrm{Fe}(\mathrm{hydr})$ oxides, clay minerals, and organic matter and it can also occur as discrete mineral phases such as carnotite $\left(\mathrm{K}_{2}\left(\mathrm{UO}_{2}\right)_{2}\left(\mathrm{VO}_{4}\right)_{2} \cdot 3 \mathrm{H}_{2} \mathrm{O}\right)$ and vanadinite $\left(\mathrm{Pb}_{5}\left(\mathrm{VO}_{4}\right)_{3} \mathrm{Cl}\right)[2,4,5]$. As an element of group $\mathrm{VB}$ and with atomic number 23 in the periodic table, it can acquire several oxidation states $(+\mathrm{III},+\mathrm{IV},+\mathrm{V})[2,6]$.

Beside its natural occurrence in soils and sediments, several anthropogenic sources can cause an enrichment or even pollution of soils and sediments with V. The main anthropogenic sources of $\mathrm{V}$ are (1) the use of $\mathrm{V}$ as a catalyst in the metal-, cement-, electronics, and textile industry; (2) the production of certain metals such as iron and uranium, with $\mathrm{V}$ as a secondary product [2], vanadium concentrations up to $738 \mathrm{mg} / \mathrm{kg}$ [7] and $3505 \mathrm{mg} / \mathrm{kg}$ [1] have been reported in mining areas; (3) air emission of $\mathrm{V}$ from the combustion of fossil fuels [8]. The majority of the emissions of $\mathrm{V}$ into the air are taken up by the soil surface, especially when soils are rich in organic matter [9]. In Flanders (Belgium), the petrochemical and chemical industry are the main anthropogenic sources for V. Other minor contributors to $\mathrm{V}$ emissions are the food industry and the non-ferro industry [10].

Most food crops and also other plants contain trace amounts of $\mathrm{V}$ [6] because small concentrations of $\mathrm{V}$ stimulate plant growth and act as a catalyst for nitrogen fixation [11]. When plants and crops are exposed to enhanced V concentrations in soil, they are usually smaller than the same plants grown on noncontaminated soils $[1,2,12]$. V concentrations in porewater above $3 \mathrm{mg} \mathrm{L}^{-1}$ result in important toxic effects for plants [3]. Kasai et al. [13] found that $0.1 \mu \mathrm{M}$ vanadate had slight effects on seed germination, growth, photosynthesis, respiration, and ATPase activity of wheat and rye grass. The use of certain fertilizers $\left(\left(\mathrm{NH}_{4}\right)_{2} \mathrm{PO}_{4}, \mathrm{Na}_{3} \mathrm{PO}_{4}\right)$ 
increases the solubility, mobility, and uptake of $\mathrm{V}$ by plants [14]. The oxidation state of $\mathrm{V}$ is primarily controlled by the Eh (redox potential) and $\mathrm{pH}$ of a system. Under oxidizing and more alkaline conditions, vanadium is found in anionic form, as vanadate $\left(\mathrm{HVO}_{4}^{2-}\right.$ or $\mathrm{H}_{2} \mathrm{VO}_{4}^{-}$, oxidation state $\left.+\mathrm{V}\right)$, whereas vanadyl $\left(\mathrm{VO}^{2+}\right.$, oxidation state $\left.+\mathrm{IV}\right)$ has cationic properties and occurs under more acid conditions [3]. Complexes with fluoride, sulfate, or oxalate can increase the solubility of $\mathrm{V}$ under oxidizing conditions [15]. Acute poisoning of cattle by uptake of $\mathrm{V}$-containing soil particles sticking to grass has been reported by McCrindle et al. [16].

Vanadium toxicity for human beings can vary widely, depending on its oxidation state. Clinical picture of poisoning (starting from $10 \mathrm{mg}$ per day) shows different toxic effects of vanadium on the respiratory, circulatory and central nervous systems, the digestive organs, kidneys, and skin [17]. In the past, $\mathrm{V}$ has also been used as a therapeutic for the treatment of diabetes.

1.2. Alluvial Soils, Overbank Sediments, Floodplain Sediments. Darnley et al. [18] made a distinction between alluvial soils according to the catchment basin size: floodplain and overbank sediments are alluvial soils of large and small floodplains, respectively, but both consist of fine-grained (siltyclay, clayey-silt) sediments. Floodplain and overbank sediments are deposited during flood events in low energy environments [19]. Overbank sediments are considered a representative sampling medium for geochemical mapping [19]. In areas of historical mining and pollution, only one overbank sediment sample is not always representative for the geochemical characteristics of a large catchment basin [20]. De Vos et al. [4] evaluated the use of overbank sediments as a medium for geochemical mapping in industrialized areas. Samples of lower overbank sediment samples (i.e., samples taken deeper in the overbank sediment profile) reflect the natural, pristine situation, while upper overbank sediments are influenced by anthropogenic chemical contamination. From an environmental point of view, the use of overbank sediments is interesting because background concentrations are an essential reference point to evaluate the pollution status of soils and sediments.

1.3. Legal Framework with regard to V Contamination. In the environmental legislation of Flanders and Wallonia (which are the two main regions in Belgium, each with an own environmental legislation), threshold vanadium concentrations are defined for emissions in air, surface water, and groundwater. Although background and intervention values are provided in the Flemish and Walloon Soil Decree for As, Cd, $\mathrm{Cr}, \mathrm{Cu}, \mathrm{Hg}, \mathrm{Ni}, \mathrm{Pb}, \mathrm{Zn}$, and organic contaminants, no norm values are provided for V. Nevertheless, several European countries established norm values for $\mathrm{V}$ in soils (Table 1).

The norm values in Table 1 differ because of the use of different models, software, and criteria with regard to human toxicology and ecotoxicology [21]. Additionally, natural (background) concentrations of trace elements in soils and sediments are dependent on soil and sediment properties (clay content, organic carbon content, etc.) and on the geo- logical substratum, which makes it difficult to compare these norm values [23]. Moreover, total concentrations of trace elements do not give a good indication of the mobility and toxicity of an element [2].

The aim of this study was (1) to evaluate the V-content of alluvial soils (overbank sediments, floodplain sediments and dredged sediment-derived soils) along some Belgian and European rivers and to compare these values with norm values established in other European countries, (2) to establish regression equations that allow to explain the $\mathrm{V}$ content in alluvial soils based on major element composition and/or physico-chemical soil properties such as clay- and organic matter content, (3) to assess the actual and potential release ("mobile" and "mobilizable" fractions resp.) of V from these soils by means of standardized European extractions and leaching tests (single extractions with $\mathrm{CaCl}_{2}$ and ammonium-EDTA). It is not the purpose of this study to propose norm values for $\mathrm{V}$ in (alluvial) soils, but the regression equations obtained in this study can be useful to establish whether $\mathrm{V}$ concentrations that are measured in alluvial soils can be considered as "normal" or not.

\section{Methodology}

\subsection{Sampling Locations and Sampling}

2.1.1. Belgian Samples. Between November 2006 and October 2009, alluvial sediments, consisting of overbank sediment- or dredged sediment-derived soils, were sampled along 3 different rivers in Belgium (Figure 1).

In northern Belgium, overbank sediment- and dredged sediment-derived soils were sampled in the catchment of the Scheldt river (catchment area in Belgium $=13336 \mathrm{~km}^{2}$ ), which is divided in 11 subcatchments, including the Leie and Demer catchments. The Leie river (north-western part of Belgium) is an important tributary of the river Scheldt and its total catchment area, consisting of Tertiary sands and clays, is about $3675 \mathrm{~km}^{2}$ (in Belgium). The Leie river is characterized by a regular flooding regime. In 1976, a part of the river was straightened and dredged sediments were stored along the river. Heavy metals in the dredged-sediment-derived soils originate from industrial activities and agriculture. Most of the dredged-sediment-derived soils are currently used as meadows or forests. The Grote Beek (Demer catchment, $1272 \mathrm{~km}^{2}$ ) river (northern Belgium) is underlain by glauconite-rich medium-grained sands (Diestian Formation). Organic- and iron-rich wetland soils have developed along this stream. The river follows a very meandering path and as a consequence several flooding zones occur along the river, which are flooded a few times a year during periods of heavy rainfall. The major source of pollution is a factory that is producing phosphate fertilizers by the refinement of phosphate ores. The majority of the alluvial soils along the Grote Beek consist of unused (i.e., not used for living, industry or agriculture) land, situated in a natural reserve.

In eastern Belgium and in the southern part of The Netherlands, overbank sediments were sampled along the Geul river (Figure 1). The Geul river, a tributary of the 
TABLE 1: Norm values for vanadium (total concentration in $\mathrm{mg} \mathrm{kg}^{-1}$ ) in soil in European countries [21, 22].

\begin{tabular}{lcccc}
\hline Country & $\begin{array}{c}\text { Negligible } \\
\text { risc }\end{array}$ & $\begin{array}{c}\text { Warning } \\
\text { risc }\end{array}$ & $\begin{array}{c}\text { Unacceptable } \\
\text { risc (residential) }\end{array}$ & $\begin{array}{c}\text { Unacceptable } \\
\text { risc (industrial) }\end{array}$ \\
\hline The Netherlands & 42 & - & 250 & - \\
Czech Republic & 180 & 340 & 450 & - \\
Slovenia & 120 & 200 & 500 & - \\
Finland & - & 100 & 150 & 250 \\
Sweden & - & - & - & - \\
Italy & - & - & 90 & 250 \\
Lithuania & - & - & 150 & - \\
Russia & - & & & - \\
\hline
\end{tabular}

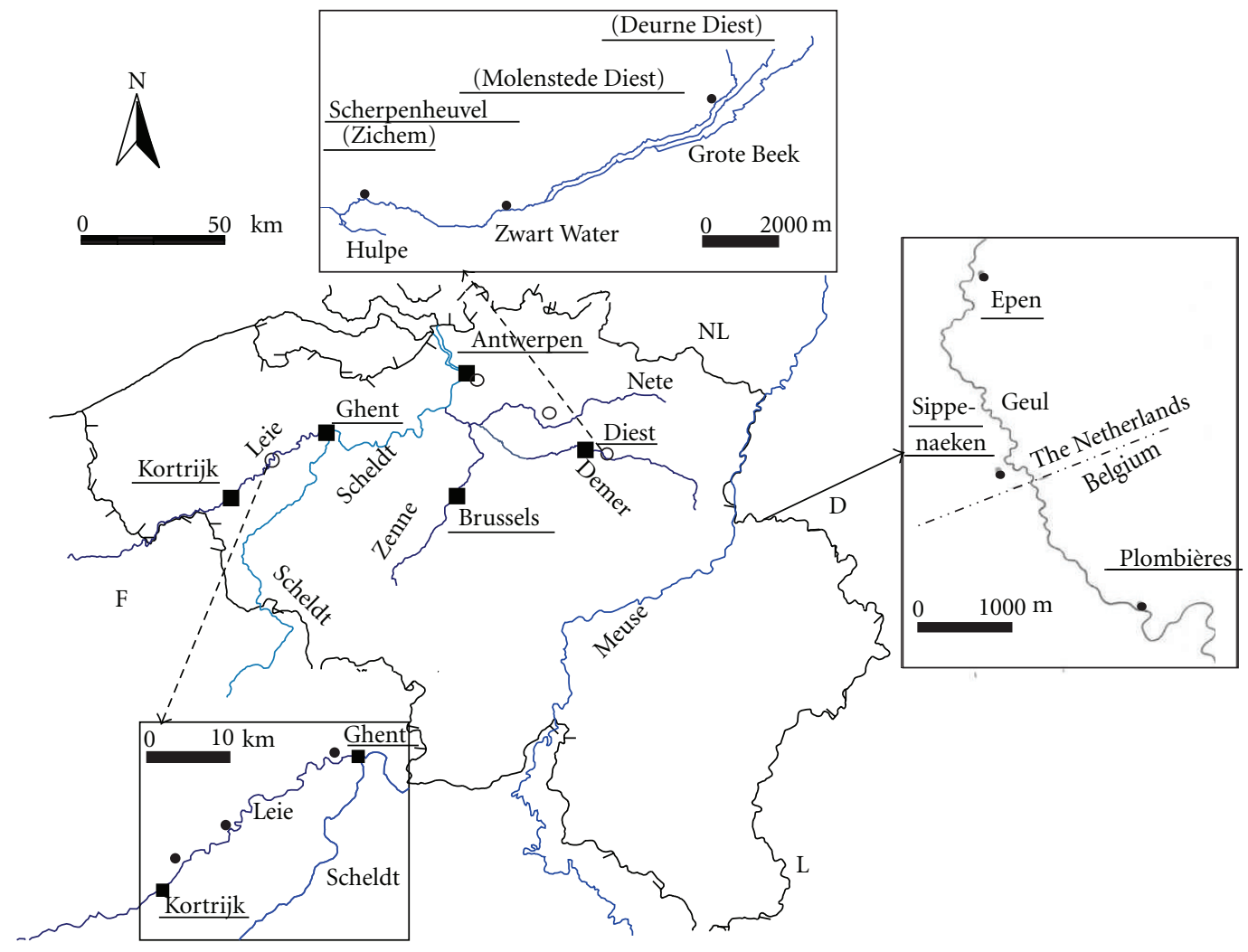

FIGURE 1: Overview of the Belgian sampling locations.

Meuse, flows in sandstones (Upper Devonian) and carbonates and shales (Lower and Middle Carbonian) [24]. The discharge of the Geul river depends largely on the amount of rainfall and is characterized by a flashy regime with a sequence of small floods in autumn and winter and a few major floods in summer [25]. From the Middle Ages until the beginning of the 20th century, extensive $\mathrm{Zn}-\mathrm{Pb}$ mining and smelting was carried out in Plombières and La Calamine (eastern Belgium). Besides the important amount of waste that is stored in the large mine tailing piles, overbank sediments along the nearby Geul river are severely contaminated with $\mathrm{Zn}, \mathrm{Pb}$, and $\mathrm{Cd}$ [24]. The Geul drains a predominantly rural catchment with a relatively low population density.

At each location, vertical profiles were dug and samples ( $1 \mathrm{~kg}$ of material per sample) were taken at depth every 5 to
$20 \mathrm{~cm}$, depending on visual differences in color, organic matter content and/or texture, yielding 3 to 5 samples per horizon. In total, 206 samples were taken. Along the Leie river, samples were taken in dredged sediment-derived soils. Along the Geul, profiles were sampled within overbank sedimentderived soils and along the Grote Beek both overbank sediment- and dredged sediment-derived soils were sampled.

2.1.2. European Samples. "The FOREGS Geochemical Baseline Mapping Programme's main aim is to provide highquality, multipurpose environmental geochemical baseline data for Europe. The need for this type of data was justified by the first Working Group on Regional Geochemical Mapping immediately after the Chernobyl accident in 1986, when it was realized that a baseline for radioactive and other 
TABLE 2: Comparison between certified and measured (average of 3 replications) values for $\mathrm{V}$ in 3 certified reference materials.

\begin{tabular}{lccc}
\hline & & Certified value $\left(\mathrm{mg} \mathrm{kg}^{-1}\right)$ & ${\mathrm{Measured} \mathrm{value}\left(\mathrm{mg} \mathrm{kg}^{-1}\right)}$ \\
SRM2710 & Montana soil & 76.6 & $69.8 \pm 4.7$ \\
GBW07311 & Soil & $47 \pm 5$ & $42.6 \pm 3.3$ \\
GBW07411 & Stream sediment & $88.5 \pm 6.9$ & $84.1 \pm 6.8$ \\
\hline
\end{tabular}

polluting elements could not be defined" [26-28]. After several attempts to compile existing regional geochemical databases in Europe, it was clear that the establishment of a harmonized European wide geochemical database was essential. The Forum of European Geological Surveys' Directors (FOREGS) approved a Geochemical Baseline Mapping Programme in 1996, and in 1997 an agreement on the principles of field and analytical methodologies was obtained and the field methodology was tested, finally resulting in the "FOREGS Geochemical Field Manual," that was published in 1998 [29]. In the present study, data from floodplain sediments samples in 26 countries that were involved in the FOREGS Geochemical Baseline Mapping Programme are used.

From each sampling site, $2 \mathrm{~kg}$ of top floodplain sediment (sampling depth $0-25 \mathrm{~cm}$ ) was collected. The sampling procedure for floodplain soils is described in the field manual [29].

\subsection{Physicochemical Soil Characterization}

\subsubsection{Belgian Alluvial Soils}

Physicochemical Characterization. All analyses were performed on air-dried soil samples. For the determination of element concentrations and organic carbon content, part of the soil sample was disaggregated in a porcelain mortar and sieved $(<1 \mathrm{~mm}) \cdot \mathrm{pH}\left(\mathrm{H}_{2} \mathrm{O}\right)$ was measured in a soil/water suspension (1/2.5). Organic carbon was determined according to the Walkley and Black method [30]. Grain size was determined by laser diffraction analyzis (Malvern Mastersizer $\mathrm{S}$ long bed). Total element concentrations ( $\mathrm{Al}, \mathrm{As}, \mathrm{Ba}, \mathrm{Cd}$, $\mathrm{Cu}, \mathrm{Cr}, \mathrm{Co}, \mathrm{Ca}, \mathrm{Fe}, \mathrm{K}, \mathrm{Mg}, \mathrm{Mn}, \mathrm{Ni}, \mathrm{Pb}, \mathrm{V}$, and $\mathrm{Zn}$ ) were determined in all the samples, but the discussion will mainly focus on V. One gram of sample was dissolved in $4 \mathrm{~mL}$ $\mathrm{HCl}_{\text {conc }}, 2 \mathrm{~mL} \mathrm{HNO}_{3 \text { conc }}$, and $2 \mathrm{~mL} \mathrm{HF}$ conc in a Teflon beaker. The mixture was gently heated on a hot plate until half dry, subsequently reattacked with the same amount of the three acids and heated until completely dry. The residue was redissolved with $20 \mathrm{~mL} 2.5 \mathrm{~mol} \mathrm{~L}^{-1} \mathrm{HCl}$ and filtered (Whatman 45). Finally, the solution was diluted to $50 \mathrm{~mL}$ with distilled water. This destruction method was chosen because we have a lot of experience with this method in our laboratory and it allows to compare the results with previous studies performed in our laboratory. Concentrations of major elements $(\mathrm{Fe}, \mathrm{Al}, \mathrm{Ca}, \mathrm{K}$, and $\mathrm{Mg}$ ) were measured with Flame atomic absorption spectrometry (FAAS, Varian AA6), whereas an Induced coupled plasma mass spectrometry (ICP-MS, HP 4500 Series) was used for As, $\mathrm{Ba}, \mathrm{Cd}, \mathrm{Cu}$, $\mathrm{Cr}, \mathrm{Co}, \mathrm{Mn}, \mathrm{Ni}, \mathrm{Pb}, \mathrm{Vm}$ and $\mathrm{Zn}$. Three certified reference materials, namely, GBW07411 Soil, (a Chinese soil),
GBW07411 sediment (a Chinese stream sediment), and SRM 2710 Montana soil (a soil collected from the upper $10 \mathrm{~cm}$ of pasture along a creek and contaminated by overbank deposition of contaminated sediments) were analyzed for quality control. Total certified V concentrations in these materials are determined by XRF and/or neutron activation analysis, whereas a dissolution with 3 strong acids $\left(\mathrm{HCl}, \mathrm{HNO}_{3}\right.$, and HF) is used in the present study, followed by a measurement with ICP-MS. Despite the use of hydrofluoric acid, a small residue (usually less than $5 \%$ of the dry mass of the sample) is not dissolved. A previous investigation in our laboratory showed that this residue consists of quartz particles and sometimes also phyllosilicates. This possibly explains why measured $\mathrm{V}$ concentrations are slightly lower compared to certified values (Table 2). Nevertheless, the use of a dissolution with strong acids and ICP-MS determination allows a better comparison with data from the FOREGS project, where $\mathrm{V}$ has been determined by ICP-MS after aqua regia dissolution and by XRF. It is clear that the procedures for the determination of total element concentrations in soils and sediments should be well established, especially in largescale studies, since this is essential to compare results of different studies and/or laboratories. Additionally, triplicate analysis was performed for some samples. Relative standard deviations on triplicate analysis ( 3 separate subsamples) were below 5\% for all elements, except Ca and $\mathrm{Al}$ (below 10\%).

Single Extractions. Single extractions were performed on 65 samples of alluvial soils from the Leie and Grote Beek rivers. For the $\mathrm{CaCl}_{2}$ and ammonium-EDTA extraction, the protocol of the SMT (Standards Measurement and Testing) program [31] was followed. $20 \mathrm{~mL}$ of a $0.01 \mathrm{~mol} \mathrm{~L}^{-1} \mathrm{CaCl}_{2}$ or $20 \mathrm{~mL}$ of a $0.05 \mathrm{~mol} \mathrm{~L}^{-1}$ ammonium-EDTA solution, respectively, was added to $2 \mathrm{~g}$ of air-dried sediment in a centrifuge tube. The suspension was shaken for $3 \mathrm{~h}$ or $1 \mathrm{~h}$, respectively, in a reciprocal shaker, centrifuged (3500 rpm, 10 minutes), decanted, and filtered $(0.45 \mu \mathrm{m})$. After measurement of $\mathrm{pH}$, the $\mathrm{CaCl}_{2}$ extract was acidified with concentrated $\mathrm{HNO}_{3}$ to bring the $\mathrm{pH}$ to $<2$. The ammonium-EDTA extracts were not acidified prior to analysis to prevent precipitation of EDTA salts at very low $\mathrm{pH}$. A reference material (CRM 483) certified for its ammonium-EDTA and $\mathrm{CaCl}_{2}$ - extractable content of $\mathrm{Cd}, \mathrm{Zn}, \mathrm{Cu}$, and $\mathrm{Pb}$ was also included. No certified values are provided for $\mathrm{V}$, but the data obtained in this study are presented in Table 3 in order to allow comparison with other studies in the future. Standard deviation between triplicate extractions was less than $5 \%$. The data of the ammoniumEDTA extracts are presented in $\mathrm{mg} / \mathrm{kg}$ dry matter, since EDTA-extractable element concentrations are often compared to total element concentrations. The $\mathrm{V}$ concentrations in the $\mathrm{CaCl}_{2}$ extracts are expressed in $\mu \mathrm{g} \mathrm{L}^{-1}$, to facilitate the 
TABLE 3: Values for $\mathrm{V}$ measured in the $\mathrm{CaCl}_{2}$ (in $\mu \mathrm{g} \mathrm{L}^{-1}$ ) and ammonium-EDTA (in $\mathrm{mg} \mathrm{kg}^{-1}$ ) extracts performed on certified reference material CRM 483 according to the BCR extraction protocol for single extractions with $\mathrm{CaCl}_{2} 0.01$ mol L ${ }^{-1}$ and ammonium-EDTA $0.05 \mathrm{~mol} \mathrm{~L}^{-1}$.

\begin{tabular}{|c|c|c|c|}
\hline & $\begin{array}{c}\mathrm{CaCl}_{2} 0.01 \mathrm{~mol} \mathrm{~L}^{-1} \\
\mu \mathrm{g} \mathrm{L}^{-1}\end{array}$ & $\begin{array}{c}\text { ammionum-EDTA } 0.05 \mathrm{~mol} \mathrm{~L}^{-1} \\
\mathrm{mg} \mathrm{kg}^{-1}\end{array}$ & $\begin{array}{c}\text { Total concentration } \\
\mathrm{mg} \mathrm{kg}^{-1}\end{array}$ \\
\hline CRM483 & $5.7 \pm 0.9$ & $4.3 \pm 0.1$ & $64.5 \pm 3.7$ \\
\hline
\end{tabular}

comparison with, for example, porewater concentrations of V.

2.2.2. Alluvial Soils from the FOREGS Database. Details about the analytical methods are provided in Sandström et al. [32]: total concentrations of $\mathrm{MgO}, \mathrm{P}_{2} \mathrm{O}_{5}, \mathrm{~K}_{2} \mathrm{O}, \mathrm{CaO}, \mathrm{TiO}_{2}$, $\mathrm{V}, \mathrm{Cr}, \mathrm{MnO}, \mathrm{Cs}, \mathrm{Ba}, \mathrm{La}$, and $\mathrm{Ce}$ were determined using energy dispersive polarized X-ray fluorescence spectrometry. In the floodplain soil samples, V was also determined by ICP-MS after aqua regia destruction. Because the data in both datasets are not always in the same order and data are sometimes missing, a comparison between data obtained with both methods was not performed. In the present study, mainly the data from the XRF analysis will be used.

2.3. Statistical Analysis. Statistical analysis was performed with the software package SPSS 16.0 for Windows.

Descriptive statistics (average, median, minimum, maximum, standard deviation, and variance) were calculated for each variable. The 90th percentile of element concentrations in the upper soil layer of noncontaminated soils is often considered representative for the background value in soils $[22,33]$. Because our datasets contained both contaminated and noncontaminated samples, no attempt was made to propose background values. By comparing average and median values, soils with enrichment in V can be detected [33].

The normal distribution of the variables was checked by means of the Kolmogorof-Smirnov (K-S) test and correlations between variables were tested by calculating two-tailed Pearson correlation coefficients for the log transformed values. Analysis of variance (ANOVA) was applied to compare averages of the variables between river basins. Multiple linear regression according to the stepwise method was performed to deduce possible causal relationships between the variables. Attention was mainly paid to the possibility of predicting trace element concentrations in sediments based on major element composition, $\mathrm{pH}$, clay, and organic matter content. Different assumptions of the linear regression (normality of the de residues, autocorrelation, quasi-multicollinearity (QMC), and heteroscedasticity) were tested.

For the statistical analysis, the recommendations of Webster $[34,35]$ (reporting mean values with standard errors, performing linear regressions, etc.) were taken into account.

\section{Results and Discussion}

3.1. Total Concentrations of $V$ in Floodplain Soils. Average total $\mathrm{V}$ concentration in the 3 Belgian catchments and in the European FOREGS database were in the range 45$87 \mathrm{mg} \mathrm{kg}^{-1}$. The high average $\mathrm{V}$ concentrations in the alluvial soils of the Grote Beek catchment is mainly due to 7 outliers with $\mathrm{V}$ concentrations between 189 and $301 \mathrm{mg} \mathrm{kg}^{-1}$. Alluvial soils of the Geul river are characterized by significant lower V concentrations compared to the Leie and Grote Beek rivers. V concentrations in floodplain soils are rarely reported in literature. Peh and Miko [36] measured average V concentrations of $70 \mathrm{mg} \mathrm{kg}^{-1}$ in Croatia, which is in line with the values reported here. Ivanov and Kashin [37] recorded (AAS-measurement after aqua regia destruction) average $\mathrm{V}$ concentrations of $110 \mathrm{mg} \mathrm{kg}^{-1}$ in alluvial deposits in Transbaikalia (Russia), and Wigginton and Price [38] found (ICPOES determination after aqua regia destruction) concentrations between 8 and $17 \mathrm{mg} \mathrm{kg}^{-1}$ in floodplain soils of Bayou Creek (UK). On the 4th October 2010, red mud suspension were released from the Ajkai Timfoldgyar Zrt alumina plant. Among other trace elements, mud samples at the source contained important $\mathrm{V}$ concentrations $\left(>1000 \mathrm{mg} \mathrm{kg}^{-1}\right)$, and floodplain sediments downstream were significantly affected by the red mud [39].

Total V concentrations in floodplain soils from the FOREGS database are represented on Figure 2. Since the data presented on Figure 2 are characterized by a right kurtosis and thus not normal distribution, concentrations represented on the map are strongly influenced by locally enhanced $\mathrm{V}$ concentrations [40]. Data for the Belgian catchments are not presented on a map, since the data originate from 3 distinct locations, only covering a limited area in Belgium.

Data observations which lied more than 1.5 interquartile range lower than the first quartile or 1.5 interquartile range higher than the third quartile were considered as an outlier. In the Belgian data for V, 7 outliers were observed, between 189-301 $\mathrm{mg} \mathrm{kg}^{-1}$, all coming from samples from the alluvial soil samples of the Grote Beek. De Grote Beek is also characterized by the highest average $\mathrm{V}$ concentrations and an important difference between average and median values for $\mathrm{V}$, which indicates an anthropogenic source for $\mathrm{V}$ [33]. In this area, phosphate ores are processed by a plant that is emitting its waste water directly into the river. $\mathrm{V}$ is known as a secondary product of phosphate production [8]. In accordance to this, the correlation coefficient between $\mathrm{V}$ and $\mathrm{P}$ in alluvial soils is also very high in the samples from the Grote Beek river.

When the $\mathrm{V}$ concentrations in these samples are compared with the norm values in Table 1, 11 samples of the Grote Beek alluvial plain exceed the value for "unacceptable risk" in residential areas established in Finland, Lithuania, and Russia ( $150 \mathrm{mg} \mathrm{kg}^{-1}$ ), whereas 3 samples exceed the Dutch "negligible risk" value of $250 \mathrm{mg} \mathrm{kg}^{-1}$. The samples from the catchment of the Leie river are contaminated with heavy metals and often characterized by an elevated clay- 


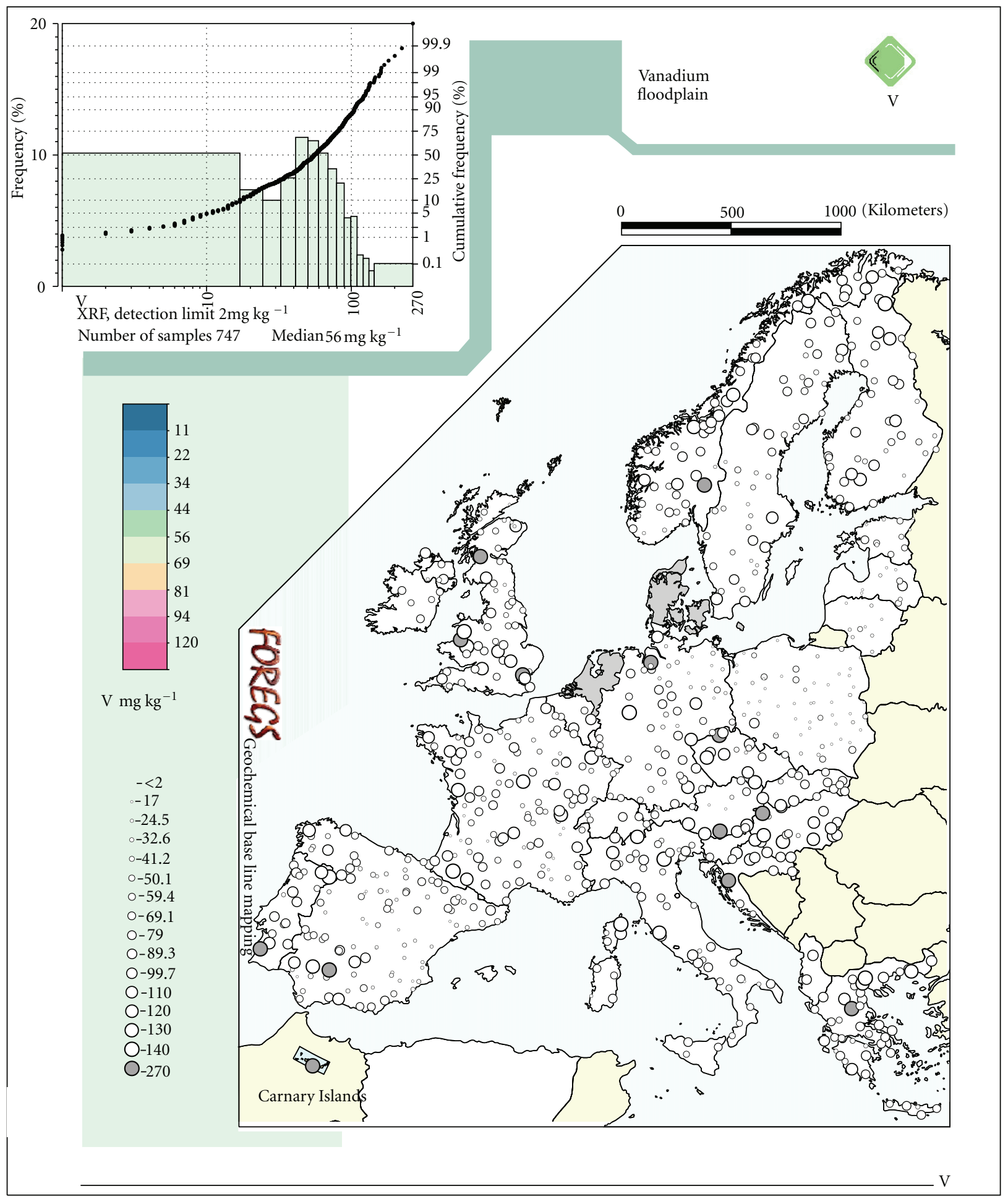

Figure 2: Total V concentrations in alluvial soils samples in 26 European countries [27]. 
TABle 4: Summary statistics for total V concentrations (in $\mathrm{mg} \mathrm{kg}^{-1}$ ), based on Belgian (this study) and European [28] data. Standard deviation is reported within brackets. $n$ : number of samples.

\begin{tabular}{|c|c|c|c|c|c|c|}
\hline dataset & area & mean & median & $\min$ & $\max$ & $n$ \\
\hline \multirow{4}{*}{ Belgian samples } & 3 Belgian floodplains & $69(43)$ & 53 & 18 & 301 & 206 \\
\hline & floodplain of the Geul & $45(6)$ & 46 & 30 & 57 & 75 \\
\hline & floodplain of the Grote Beek & $87(55)$ & 66 & 28 & 301 & 94 \\
\hline & floodplain of the Leie & $71(28)$ & 69 & 18 & 160 & 37 \\
\hline \multirow{2}{*}{ FOREGS } & Europe (XRF) & $59(35)$ & 56 & 1 & 266 & 749 \\
\hline & Europe (aqua regia) & 56 & & & & 747 \\
\hline
\end{tabular}

and organic matter content. Only one sample from alluvial plain of the Leie river is characterized by a $\mathrm{V}$ content above $150 \mathrm{mg} \mathrm{kg}^{-1}$ (total $\mathrm{V}$ concentration is $161 \mathrm{mg} \mathrm{kg}^{-1}$ ).

The samples from the Geul-catchment, finally, are characterized by relatively low total $\mathrm{V}$ concentrations (average $45 \mathrm{mg} \mathrm{kg}^{-1}$, Table 4). The average $\mathrm{V}$ concentration in the alluvial soils of the Geul river is below the 90th percentile of the European dataset, which could be considered as the background value [33], as well as below the average V concentration in European alluvial soils. The maximal V concentrations is $57 \mathrm{mg} \mathrm{kg}^{-1}$ (Table 4) and thus below all threshold values established in Table 1, except the value for "negligible risk" from The Netherlands $\left(42 \mathrm{mg} \mathrm{kg}^{-1}\right)$. The average $\mathrm{V}$ concentration in the soils along the Geul is very close to the median concentration, which indicates that $\mathrm{V}$ is not of anthropogenic origin [33]. The subsoil in the Geul catchment consists of sand and shale and other studies also showed that total $\mathrm{V}$ concentrations in soils developed on shale are lower compared to more clay-rich substrates [41].

In the European FOREGS dataset, "the spatial distribution of $\mathrm{V}$ is clearly related to the bedrock geology and mineralization, especially mafic and ultramafic lithology, and also clay-rich soil with high $\mathrm{Al}_{2} \mathrm{O}_{3}$ content" [15]. The highest $\mathrm{V}$ concentration is found in the mineralized Oslo rift $\left(266 \mathrm{mg} \mathrm{kg}^{-1}\right)$. In England and Germany, elevated V concentrations $\left(224 \mathrm{mg} \mathrm{kg}^{-1}\right)$ are respectively due to industrial pollution and coal and oil combustion [15].

\subsection{Relation of $V$ with Other Elements}

3.2.1. Correlations. Because the majority of the data (trace element and major element concentrations) showed a right kurtosis and were significant on the K-S test, the data were $\log$ transformed. Concerning the FOREGS data, the correlation coefficients in Table 5 were calculated with the data from the XRF determination, since more elements that are relevant for this paper were measured with this method compared with the aqua regia method. Unfortunately, it was not possible to merge the results of the aqua regia and XRF determination into one table, because the data were not in the same order and there were several missing samples for each of the methods. This inconvenience of the FOREGS database has also been mentioned by [40].

In general, $\mathrm{Mg}, \mathrm{Cr}$, and $\mathrm{Al}$ showed the strongest correlation with $\mathrm{V}$ (Table 5). Among the trace elements, $\mathrm{Cr}$ is characterized by a strongly positive correlation with $\mathrm{V}$ in the samples of the Grote Beek $(R=0.933)$. Other studies also demonstrated a high correlation between $\mathrm{Cr}$ and $\mathrm{V}$ in soils and sediments [23, 42]. $\mathrm{Cr}$ and $\mathrm{V}$ can substitute for each other in the crystal structure of clay minerals and vanadate and chromate show a similar behavior in soils.

In the catchment of the Grote Beek, elevated Fe concentrations were generally found, with a maximal concentration of $7.66 \% \mathrm{Fe}$, which could be explained by the occurrence of iron-bearing sands and sandstone as well as glauconite in the subsoil [43].

$\mathrm{Fe}$ and $\mathrm{Al}$ also show a positive correlation, which is often observed in soils and sediments (e.g., [15, 42, 44-46]).

Data for the clay and organic carbon content were only available for the floodplain soils of the Leie. Vanadium shows a significant positive correlation with the clay content (0.713), which is in accordance with the positive correlation with $\mathrm{Al}$ and other clay-associated elements and with the organic carbon content $(0.657)$. Although the association of $\mathrm{V}$ with organic material is also shown in other studies $[2,46]$, some authors [42] report a significant negative correlation between $\mathrm{V}$ and organic matter content. Połedniok and Buhl [5] concluded that the amount of $\mathrm{V}$ bound to organic material is lower in industrial areas compared to rural areas.

For the XRF-data from the FOREGS database, vanadium in the European floodplain soil samples is strongly positively correlated with $\mathrm{Fe}$ and $\mathrm{Ti}$, and to a lesser extent with $\mathrm{Al}$.

These positive correlations can be explained by the fact that (hydr)oxides of $\mathrm{Fe}, \mathrm{Ti}$ and $\mathrm{Al}$ are good adsorbers for $\mathrm{V}$ ions $[47,48]$ and because of the occurrence of these elements in clay minerals. Moreover, the atomic radius of the $\mathrm{V}$ ion is similar to the radius of $\mathrm{Fe}$ and $\mathrm{Al}[2,15]$.

\subsubsection{Regression Equations to Predict $V$ Concentrations in} Alluvial Soils. Multiple linear regressions were performed with $\mathrm{Fe}, \mathrm{Mg}, \mathrm{Ca}, \mathrm{K}, \mathrm{Al}, \mathrm{P}$, and the clay $(<2 \mu \mathrm{m}$ fraction), and organic matter content as independent variables. Clay and organic matter were included because they are already used in the standardization of background values for heavy metals in soils and sediments [49]. Fe is a major component of $\mathrm{Fe}$ (hydr)oxides, and is also a constituent of sheet silicates. In soils and sediments, $\mathrm{Ca}$ and $\mathrm{Mg}$ are dominantly found in sheet silicates when the parent material is Mg-rich (e.g., ultrabasic rocks) and in carbonate minerals (e.g., $\mathrm{CaCO}_{3}$ ) in nonacidic soils.

Regression equations were constructed according to the stepwise method [50]. In order to only include the most significant independent variables. With exception of the soils from the Grote Beek, all regression equations in Table 6 are 
TABle 5: Two-tailed Pearson correlation coefficients of $\mathrm{V}$ with other elements measured in floodplain soils of Belgian and European rivers.

\begin{tabular}{|c|c|c|c|c|c|}
\hline & Belgian data & Grote Beek & Geul & Leie & FOREGS \\
\hline $\mathrm{Mg}$ & $0.793^{* *}$ & $0.821^{* *}$ & $0.391^{* *}$ & $0.778^{* *}$ & $0.570^{* *}$ \\
\hline $\mathrm{Al}$ & 0.030 & $0.785^{* *}$ & $0.686^{* *}$ & $0.870^{*}$ & $0.680^{* *}$ \\
\hline $\mathrm{P}$ & $0.626^{* *}$ & $0.556^{* *}$ & -0.028 & 0.280 & $0.374^{* *}$ \\
\hline K & $0.681^{* *}$ & $0.343^{* *}$ & - & $0.605^{* *}$ & $0.433^{* *}$ \\
\hline $\mathrm{Ca}$ & $0.481^{* *}$ & 0.088 & -0.100 & 0.170 & 0.064 \\
\hline $\mathrm{Cr}$ & $0.729^{* *}$ & $0.933^{* *}$ & 0.177 & $0.631^{* *}$ & $0.665^{* *}$ \\
\hline $\mathrm{Mn}$ & -0.079 & $0.516^{* *}$ & 0.211 & $0.397^{*}$ & $0.640^{* *}$ \\
\hline $\mathrm{Fe}$ & $0.668^{* *}$ & -0.118 & $0.461^{* *}$ & $0.827^{* *}$ & $0.896^{* *}$ \\
\hline Co & $0.201^{* *}$ & $0.825^{* *}$ & $0.399 * *$ & $0.672^{* *}$ & $0.841^{* *}$ \\
\hline $\mathrm{Ni}$ & $0.424^{* *}$ & $0.551^{* *}$ & $0.322 * *$ & $0.717^{* *}$ & $0.706^{* *}$ \\
\hline $\mathrm{Cu}$ & $0.513^{* *}$ & $0.651^{* *}$ & $0.235^{*}$ & $0.484^{* *}$ & $0.649^{* *}$ \\
\hline $\mathrm{Zn}$ & 0.021 & $0.665^{* *}$ & 0.152 & $0.382^{*}$ & $0.556^{* *}$ \\
\hline As & $0.575^{* *}$ & $0.411^{* *}$ & $0.249^{*}$ & $0.594^{* *}$ & - \\
\hline $\mathrm{Se}$ & $0.468^{* *}$ & $0.365^{*}$ & 0.184 & $0.715^{* *}$ & - \\
\hline $\mathrm{Sr}$ & $0.667^{* *}$ & $0.548^{* *}$ & $0.601^{* *}$ & $0.375^{*}$ & - \\
\hline $\mathrm{Cd}$ & $0.428^{* *}$ & $0.314^{* *}$ & 0.121 & $0.365^{*}$ & - \\
\hline $\mathrm{Ba}$ & $0.439 * *$ & $0.437^{* *}$ & $0.561^{* *}$ & $0.628^{* *}$ & $0.463^{* *}$ \\
\hline $\mathrm{Pb}$ & -0.128 & $0.615^{* *}$ & 0.211 & $0.461^{* *}$ & $0.347^{* *}$ \\
\hline $\mathrm{Ti}$ & - & - & - & - & $0.869^{* *}$ \\
\hline $\mathrm{OM}$ & - & - & - & $0.657^{* *}$ & - \\
\hline Clay & - & - & - & $0.713^{* *}$ & - \\
\hline Loam & - & - & - & 0.054 & - \\
\hline Sand & - & - & - & $-0.511^{* *}$ & - \\
\hline$S$ & - & - & - & $0.463^{*}$ & - \\
\hline
\end{tabular}

*: significant at $\alpha=0.05$ (two-tailed).

**: significant at $\alpha=0.01$ (two-tailed).

characterized by one or more outliers. Omission of the outliers from the dataset resulted in a better fit for the regression equations (Table 6). Additionally, the QMC, homoscedasticity, normality of the residues in independent residues improved in most of the cases.

In general, total $\mathrm{V}$ concentrations could be predicted very well by the independent variables $\mathrm{Al}, \mathrm{Fe}$, and $\mathrm{Mg}$ (Table 6). An example of a good fit between measured and predicted values is presented in Figure 3 for the alluvial soils of the Leie.

For the Belgian dataset, $\mathrm{Al}$ was an important explaining variable, together with $\mathrm{Fe}, \mathrm{Mg}$, and/or $\mathrm{P}$ (Table 3). Particularly for the Grote Beek alluvial soils, $\mathrm{P}$ is an explaining variable in the regression equation for $\mathrm{V}$, which can be related to the emissions from the phosphate ore processing plant.

Despite the fact that major elements such as Fe, and $\mathrm{Mg}$ are also a component of sheet silicates, they are also major components of resp. Fe-(hydr)oxides and carbonates. Moreover, the attribution of the term "clay fraction" to the $<2 \mu \mathrm{m}$ fraction is sometimes misleading. Beside clay minerals, Ferich minerals such as $\mathrm{Fe}$-oxi/hydroxides and phyllosilicates are often concentrated in the clay fraction $(<2 \mu \mathrm{m})$ [51]. A geochemical approach using the total concentrations of conservative elements may be used to overcome these difficulties (e.g., [52]). Before processing the dataset, the potential anthropogenic input of the element and diagenetic processes that may alter its concentrations in sediments should be checked [53]. For the European data, Fe, Al, and $\mathrm{Mg}$ were the most significant explaining variables (Table 6).

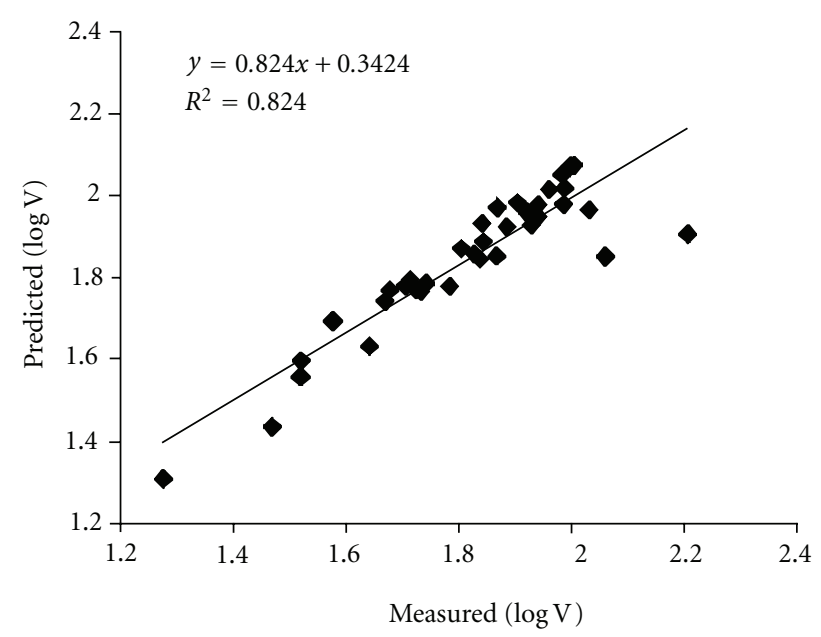

Figure 3: Predicted versus measured V concentrations in the floodplain soils of the Leie river.

\subsection{Single Extractions}

3.3.1. Prediction of "Mobile" Metal Concentrations. The composition of soil porewater is important from an environmental point of view because it gives an indication of the "actual mobility" of heavy metals and because the uptake of trace elements by plants occurs via the porewater. Moreover, porewater is also the carrier for elements to the groundwater. 
TABLE 6: Regression equations for the different areas with V (logtransformed) as dependent variable.

\begin{tabular}{|c|c|c|}
\hline Area & Regression equation & $R^{2}$ \\
\hline \multirow{2}{*}{$\begin{array}{l}3 \text { Belgian } \\
\text { floodplains }\end{array}$} & ${ }^{\mathrm{a}} \log \mathrm{V}=-3.172+0.433 \log \mathrm{Al}+0.367 \log \mathrm{Mg}+0.399 \log \mathrm{Fe}+0.058 \log \mathrm{P}^{* *}$ & 0.831 \\
\hline & ${ }^{\mathrm{b}} \log \mathrm{V}=-2.956+0.424 \log \mathrm{Al}+0.341 \log \mathrm{Mg}+0.312 \log \mathrm{Fe}+0.068 \log \mathrm{P}^{* *}$ & 0.920 \\
\hline \multirow{2}{*}{$\begin{array}{l}\text { floodplain of the } \\
\text { Geul }\end{array}$} & ${ }^{\mathrm{a}} \log \mathrm{V}=-1.424+0.507 \log \mathrm{Al}+0.174 \log \mathrm{Fe}^{* *}$ & 0.606 \\
\hline & ${ }^{\mathrm{b}} \log \mathrm{V}=-1.342+0.503 \log \mathrm{Al}+0.160 \log \mathrm{Fe}^{* *}$ & 0.634 \\
\hline $\begin{array}{l}\text { floodplain of the } \\
\text { Grote Beek }\end{array}$ & ${ }^{\mathrm{a}} \log \mathrm{V}=-2.820+0.761 \log \mathrm{Al}+0.196 \log \mathrm{Mg}+0.207 \log \mathrm{P} * *$ & 0.809 \\
\hline \multirow{2}{*}{$\begin{array}{l}\text { floodplain of the } \\
\text { Leie }\end{array}$} & ${ }^{\mathrm{a}} \log \mathrm{V}=-4.244+0.945 \log \mathrm{Al}+0.368 \log \mathrm{Mg}+0.315 \log$ clay** & 0.824 \\
\hline & ${ }^{\mathrm{b}} \log \mathrm{V}=-3.870+0.775 \log \mathrm{Al}+0.472 \log \mathrm{Mg}+0.330 \log$ clay** & 0.900 \\
\hline \multirow{2}{*}{ Europe } & ${ }^{\mathrm{a}} \log \mathrm{V}=1.041+1.32 \log \mathrm{Fe}+0.413 \log \mathrm{Al}+0.102 \log \mathrm{Mg}^{* *}$ & 0.836 \\
\hline & ${ }^{\mathrm{b}} \log \mathrm{V}=1.108+1.33 \log \mathrm{Fe}+0.279 \log \mathrm{Al}+0.086 \log \mathrm{Mg}^{* *}$ & 0.880 \\
\hline
\end{tabular}

${ }^{\mathrm{a}}$ In the first regression equation, outliers are included. ${ }^{\mathrm{b}}$ The second regression equation is without outliers. ${ }^{* *}$ Significant at 0.01 level.

The composition of the $\mathrm{CaCl}_{2}$ extract is often considered representative for porewater composition. Contaminants in the porewater can move to deeper soil layers or to the groundwater by infiltrating water. In the present study, average $\mathrm{CaCl}_{2}$-extractable $\mathrm{V}$ concentrations were $2 \mu \mathrm{g} \mathrm{L}^{-1}$ for the samples from the Leie and $4 \mu \mathrm{g} \mathrm{L}^{-1}$ for the samples from the Grote Beek (Table 7), which is far below the value of $3 \mathrm{mg} \mathrm{L}^{-1}$, which is proposed by Edwards et al. [3] and would cause significant toxic effects to plants.

Metal partitioning in soils can be quantified by models in which metal concentrations in the porewater are described as a function of the metal binding solid phases such as Fe- and $\mathrm{Al}$-(hydr)oxides, organic matter, and clay and as a function of soil characteristics that influence heavy metal partitioning, such as $\mathrm{pH}$. The ratio between total metal content bound to a soil relative to its concentration in the soil solution is often represented by $K_{d}$ coefficients. However, such a model assumes that the sorption capacity of a material is independent of the soil properties (organic matter content, $\mathrm{pH}$, clay content, etc.) and therefore, single $K_{d}$ values are not appropriate to predict metal solubility in soil. Therefore, several authors indicated that metal solubility could be predicted from soil properties. For example, Houba et al. [54] observed a significant relationship between the distribution coefficient $\left(K_{d}\right)$ of $\mathrm{Cd}$ in soils and the $\mathrm{pH}$ of the $\mathrm{CaCl}_{2}$ extract. According to McBride et al. [55] most of the variability of metal solubility in soil is explained by $\mathrm{pH}$, organic matter content and total metal concentrations.

A semimechanistic approach was developed by Sauvé et al. [56] which is based on the assumption that exchangeable metals and protons compete for adsorption on soil-exchange sites. In this model, $\mathrm{pH}$, total metal concentrations, and soil organic matter are used to predict dissolved metal concentrations.

In the present study, a modified version of this competitive adsorption model was applied, since ammonium-EDTAextractable metal concentrations were used instead of total metal concentrations. EDTA extractions are often used to estimate the potentially "available pool" of metals (i.e., the pool that can deliver metals from the solid phase of the soil to the soil solution in a relatively short time period). Stepwise multiple linear regressions was performed with $\mathrm{pH}\left(\mathrm{CaCl}_{2}\right)$, organic carbon content, clay content, $\mathrm{CaCl}_{2}$-extractable $\mathrm{V}$ in $\mathrm{P}$ concentrations, dissolved organic carbon (DOC) content in the $\mathrm{CaCl}_{2}$-extracts, and ammonium-EDTA-extractable $\mathrm{V}$ in $\mathrm{P}$ concentrations. Phosphorus was included because phosphate can influence the release of $\mathrm{V}$ from soils $[7,13,57]$.

The distribution of an element between the liquid and solid phase depends strongly on the speciation of the selected element. Because vanadium is known to occur in multiple oxidation states, the actual distribution of the oxidation states was first calculated using the speciation code VisualMinteQ. According to these calculations, the main vanadium species encountered in the $\mathrm{CaCl}_{2}$ extracts is $\mathrm{HVO}_{4}^{2-}$, which means that $\mathrm{V}$ occurs as an anion that will have the tendency to be desorbed when $\mathrm{pH}$ rises.

For the Grote Beek floodplain soils, only the $\mathrm{pH}$ of the $\mathrm{CaCl}_{2}$ extract and ammonium-EDTA-extractable $\mathrm{V}$ concentrations were retained in the final regression model, as the other variables did not contribute to an improvement of the regression equation. For the Grote Beek river catchment, "mobile" V concentrations in floodplain soils could be predicted using the following fitting equation:

$$
\begin{aligned}
\log [\mathrm{V}]_{\mathrm{s}} & =5.356-1.041 \mathrm{pH}+1.338 \log [\mathrm{V}]_{\mathrm{a}} \\
R^{2} & =0.840
\end{aligned}
$$

with $[\mathrm{V}]_{\mathrm{s}}=$ the $\mathrm{V}$ concentration in the $\mathrm{CaCl}_{2}$ extract ( $\left.\mathrm{mg} \mathrm{L}^{-1}\right),[\mathrm{V}]_{\mathrm{a}}=$ the "available pool" of $\mathrm{V}\left(\mathrm{mg} \mathrm{kg}^{-1}\right)$.

For the floodplain soils along the Leie, the $\mathrm{pH}$ of the $\mathrm{CaCl}_{2}$ extract, EDTA-extractable V-concentrations and organic carbon content were retained in the final regression model, resulting in the following regression equation:

$$
\begin{aligned}
\log [\mathrm{V}]_{\mathrm{s}}= & 1.313-1.969 \log \text { clay }+0.378 \log [\mathrm{P}]_{\mathrm{a}} \\
& +1.150 \log \text { OC } \\
R^{2}= & 0.590
\end{aligned}
$$


TABLe 7: Summary statistics for $\mathrm{V}$ concentrations in the $\mathrm{CaCl}_{2}$ (in $\mu \mathrm{g} \mathrm{L}^{-1}$ ) and ammonium-EDTA (in mg $\mathrm{kg}^{-1}$ ) extracts. Standard deviation is reported within brackets. $n$ : number of samples.

\begin{tabular}{|c|c|c|c|c|c|}
\hline & mean & median & $\min$ & $\max$ & $n$ \\
\hline \multicolumn{6}{|l|}{ Leie river } \\
\hline $\mathrm{CaCl}_{2}\left(\mu \mathrm{g} \mathrm{L}^{-1}\right)$ & $2.0(1.7)$ & 1.8 & $<0.1$ & 6.7 & 39 \\
\hline ammonium-EDTA ( $\left.\mathrm{mg} \mathrm{kg}^{-1}\right)$ & $2.4(2.2)$ & 2.0 & $<0.1$ & 9.8 & 39 \\
\hline \multicolumn{6}{|l|}{ Grote Beek river } \\
\hline $\mathrm{CaCl}_{2}\left(\mu \mathrm{g} \mathrm{L}^{-1}\right)$ & $4.4(4.5)$ & 2.0 & $<0.1$ & 12.2 & 27 \\
\hline ammonium-EDTA ( $\left.\mathrm{mg} \mathrm{kg}^{-1}\right)$ & $11.2(12.1)$ & 5.0 & 1.3 & 35.3 & 27 \\
\hline
\end{tabular}

with $[\mathrm{V}]_{\mathrm{s}}=$ the $\mathrm{V}$ concentration in the $\mathrm{CaCl}_{2}$ extract $\left(\mathrm{mg} \mathrm{L}^{-1}\right),[\mathrm{P}]_{\mathrm{a}}=$ the "available pool" of $\mathrm{P}\left(\mathrm{mg} \mathrm{kg}^{-1}\right), \mathrm{OC}$ $=$ the organic carbon content $(\%)$, clay $=$ the clay content (in \%).

3.3.2. "Potential Availability" of $V$. Ammonium-EDTA was also used to estimate the "mobilizable" metal concentrations. EDTA is a nonselective reagent that exhibits a strong capacity to complex metals. EDTA was shown to dissolve carbonates, thereby mobilizing occluded elements [58]. Borggaard [59] showed that EDTA extracts amorphous Fe-oxides, but this dissolution is very slow in the presence of other metalchelate complexes [60]. It is also able to form organometal complexes, which compete with organic matter in soil. Additionally, complexes of EDTA with heavy metals such as Cd, $\mathrm{Cu}, \mathrm{Pb}, \mathrm{Ni}$, and $\mathrm{Zn}$ are more stable than complexes between $\mathrm{V}$ and EDTA, which results in a lower ammonium-EDTAextractable fraction of $\mathrm{V}$ when the heavy metals mentioned before are present in high concentrations [61]. The average EDTA-extractable $\mathrm{V}$ concentration in the floodplain soils of the Leie was $2.46 \mathrm{mg} \mathrm{kg}^{-1}$ (Table 7) which is comparable with average EDTA-extractable $\mathrm{V}$ concentrations $\left(3.40 \mathrm{mg} \mathrm{kg}^{-1}\right)$ reported by Gäbler et al. [61]. In the samples from the Grote Beek river, the average ammonium-EDTA-extractable $\mathrm{V}$ concentration was $11.2 \mathrm{mg} / \mathrm{kg}$. Floodplain soil samples along the Grote Beek are contaminated with $\mathrm{V}$ and display elevated $\mathrm{V}$ concentrations, which can also explain for the higher 'potentially mobile $\mathrm{V}$-content in these soils. In relative concentrations, however, only $3.5 \%$ and $9.8 \%$ of the total V content in the floodplain soil samples of, respectively, the Leie and the Grote Beek were extracted with ammoniumEDTA, pointing to the fact that the majority of the $\mathrm{V}$ in the samples is characterized by a very low mobility. In the highly contaminated samples of the Grote Beek, a more detailed study of $\mathrm{V}$ mobility may nevertheless be useful to elucidate the potential release of $\mathrm{V}$ under changing environmental conditions (changes in $\mathrm{pH}, \mathrm{Eh}$, etc.).

\section{Conclusion}

Average $\mathrm{V}$ concentrations in Belgian alluvial soils $\left(69 \mathrm{mg} \mathrm{kg}^{-1}\right)$ are in general comparable with the average $\mathrm{V}$ content in European alluvial soils $\left(56-59 \mathrm{mg} \mathrm{kg}^{-1}\right)$. In one of the river catchments analyzed in this study, a contamination of alluvial soils, originating from a phosphate ore processing plant, was detected. By analysis of both the Belgian and European data, the relationship between concentrations of major elements and $\mathrm{V}$ was quantified. $\mathrm{Fe}, \mathrm{Al}$, and $\mathrm{Mg}$ were the most significant variables that could predict the total $\mathrm{V}$ content in the alluvial soils and the obtained regression equation could be used to predict $\mathrm{V}$ concentrations in alluvial soils. For the alluvial soils contaminated by the emissions from the phosphate ore treatment plant, $\mathrm{P}$ was also an explaining variable. "Mobile" V concentrations, as estimated by the amount of $\mathrm{V}$ released by a single extraction with $\mathrm{CaCl}_{2} 0.01 \mathrm{~mol} \mathrm{~L}^{-1}$, were low, even in the most contaminated soil samples. Despite the low actual mobility of $\mathrm{V}$, it might nevertheless be useful to study the effect of changing environmental conditions such as soil acidification and fluctuating redox conditions (e.g., by inundation of the floodplain soils). This will be the subject of a followup study, in order to obtain a better insight in the geochemistry of $\mathrm{V}$ in soils and sediments.

Finally, it is clear that the procedures for the determination of total element concentrations in soils and sediments should be well established, especially in large-scale studies, since this is essential to compare results of different studies and/or laboratories.

\section{References}

[1] N. Panichev, K. Mandiwana, D. Moema, R. Molatlhegi, and P. Ngobeni, "Distribution of vanadium(V) species between soil and plants in the vicinity of vanadium mine," Journal of Hazardous Materials, vol. 137, no. 2, pp. 649-653, 2006.

[2] R. D. Schuiling, R. J. van Enk, and H. L. T. en Bergsma, "Natuurlijk voorkomen, mobiliteit en industrieel gebruik van "exoten" voorkomend in de Nederlandse bodem (Br, I, Ba, Sb, V, Sn, Co, Mo, Se)," 2003, http://www.geochem.nl/.

[3] R. Edwards, N. W. Lepp, and K. C. Jones, "Other less abundant elements of potential significance," in Heavy Metals in Soils, B. J. Alloway, Ed., pp. 307-352, Blackie Academic/Chapman and Hall, London, UK, 2nd edition, 1995.

[4] W. De Vos, J. Ebbing, R. Hindel, J. Schalich, R. Swennen, and I. Van Keer, "Geochemical mapping based on overbank sediments in the heavily industrialised border area of Belgium, Germany and the Netherlands," Journal of Geochemical Exploration, vol. 56, no. 2, pp. 91-104, 1996.

[5] J. Połedniok and F. Buhl, "Speciation of vanadium in soil," Talanta, vol. 59, no. 1, pp. 1-8, 2003.

[6] D. G. Barceloux, "Vanadium," Clinical Toxicology, vol. 37, no. 2, pp. 265-278, 1999.

[7] Y. Teng, X. Jiao, J. Wang, W. Xu, and J. Yang, "Environmentally geochemical characteristics of vanadium in the topsoil in the Panzhihua mining area, Sichuan Province, China," Chinese Journal of Geochemistry, vol. 28, no. 1, pp. 105-111, 2009. 
[8] World Health organization (WHO), Vanadium Pentoxide and Other Inorganic Vanadium Compounds, WHO, Genève, Switzerland, 2001.

[9] B. J. Alloway, Heavy Metals in Soils, Chapman and Hall, London, UK, 1995.

[10] P. Lodewijks, C. Polders, K. Briffaerts, and H. Van Rompaey, "Evaluatie emissiereductiepotentieel voor diverse polluentemissies naar de lucht van de chemische sector, deel II, Eindrapport," Evaluation of the potential reduction of industrial emissions from the chemical sector, Part 2, Final report II. Study ordered by Aminal, Environmental Policy section, 2004/IMS/R/186, August 2004.

[11] J. R. Benemann, C. E. McKenna, R. F. Lie, T. G. Traylor, and M. D. Kamen, "The vanadium effect in nitrogen fixation by azotobacter," Biochimica et Biophysica Acta, vol. 264, no. 1, pp. 25-38, 1972.

[12] A. Olness, R. Gesch, F. Forcella, D. Archer, and J. Rinke, "Importance of vanadium and nutrient ionic ratios on the development of hydroponically grown cuphea," Industrial Crops and Products, vol. 21, no. 2, pp. 165-171, 2005.

[13] M. Kasai, J. Yamazaki, M. Kikuchi, M. Iwaya, and S. Sawada, "Concentration of vanadium in soil water and its effect on growth and metabolism of rye and wheat plants," Communications in Soil Science and Plant Analysis, vol. 30, no. 7-8, pp. 971-982, 1999.

[14] K. L. Mandiwana and N. Panichev, "The leaching of vana$\operatorname{dium}(\mathrm{V})$ in soil due to the presence of atmospheric carbon dioxide and ammonia," Journal of Hazardous Materials, vol. 170, no. 2-3, pp. 1260-1263, 2009.

[15] W. De Vos and T. Tarvainen, Eds., Geochemical Atlas of Europe Part 2: Interpretation of Geochemical Mops, Additional Tables, Figures, Maps and Related Publications, EuroGeosurveys \& Foregs, Espoo, Finland, 2006.

[16] C. M. E. McCrindle, E. Mokantla, and N. Duncan, "Peracute vanadium toxicity in cattle grazing near a vanadium mine," Journal of Environmental Monitoring, vol. 3, no. 6, pp. 580$582,2001$.

[17] B. Mukherjee, B. Patra, S. Mahapatra, P. Banerjee, A. Tiwari, and M. Chatterjee, "Vanadium-an element of atypical biological significance," Toxicology Letters, vol. 150, no. 2, pp. 135143, 2004.

[18] A. G. Darnley, A. Björklund, B. Bölviken et al., A Global geochemical database for environmental and resource management. Final report of IGCP Project 259, Earth Sciences 19, UNESCO Publishing, Paris, France, 1995.

[19] R. T. Ottesen, J. Bogen, B. Bølviken, and T. Volden, “Overbank sediment: a representative sample medium for regional geochemical mapping," Journal of Geochemical Exploration, vol. 32, no. 1-3, pp. 257-277, 1989.

[20] J. Ridgway, D. M. A. Flight, B. Martiny, A. Gomez-Caballero, C. Macias-Romo, and K. Greally, "Overbank sediments from central Mexico: An evaluation of their use in regional geochemical mapping and in studies of contamination from modern and historical mining," Applied Geochemistry, vol. 10, no. 1, pp. 97-109, 1995.

[21] J. Provoost, C. Cornelis, and F. Swartjes, "Comparison of soil clean-up standards for trace elements between countries: why do they differ?" Journal of Soils and Sediments, vol. 6, no. 3, pp. 173-181, 2006.

[22] C. Carlon, Ed., Derivation methods of soil screening values in Europe. A review and evaluation of national procedures towards harmonization, European Commission, Joint Research Centre, Ispra, Italy, 2007.
[23] D. J. Spurgeon, P. Rowland, G. Ainsworth, P. Rothery, S. Long, and H. I. J. Black, "Geographical and pedological drivers of distribution and risks to soil fauna of seven metals $(\mathrm{Cd}, \mathrm{Cu}$, $\mathrm{Cr}, \mathrm{Ni}, \mathrm{Pb}, \mathrm{V}$ and $\mathrm{Zn}$ ) in British soils," Environmental Pollution, vol. 153, no. 2, pp. 273-283, 2008.

[24] R. Swennen, I. VanKeer, and W. DeVos, "Heavy metal contamination in overbank sediments of the Geul River (east Belgium): its relation to former $\mathrm{Pb}-\mathrm{Zn}$ mining activities," Environmental Geology, vol. 24, no. 1, pp. 12-21, 1994.

[25] H. Leenaers, "The transport of heavy metals during flood events in the polluted River Geul (The Netherlands)," Hydrological Processes, vol. 3, no. 4, pp. 325-338, 1989.

[26] B. Bølviken, J. Bogen, W. De Vos et al., "Final report of the Working Group on Regional Geochemical Mapping 19861993. Forum of European Geological Surveys (FORGES)," Geological Survey of Norway (NGU) Open File Report 93.092, 1993.

[27] B. Bölviken, J. Bogen, A. Demetriades et al., "Regional geochemical mapping of Western Europe towards the year 2000," Journal of Geochemical Exploration, vol. 56, no. 2, pp. 141-166, 1996.

[28] R. Salminen, M. J. Batista, M. Bidovec, and A. Demetriades, Geochemical Atlas of Europe. Part 1: Background Information, Methodology and Maps, EuroGeosurveys \& Foregs, Espoo, Finland, 2005.

[29] R. Salminen, T. Tarvainen, A. Demetriades et al., FOREGS geochemical mapping field manual, Geological Survey of Finland, Guide 47, 1998.

[30] D. W. Nelson and L. E. Sommers, "Total carbon, organic carbon and organic matter," in Methods of Soil Analysis. Part 2: Chemical and Microbiological Properties, pp. 516-593, American Society of Agronomy, Madison, Wis, USA, 2nd edition, 1982.

[31] P. Quevauviller, "Operationally defined extraction procedures for soil and sediment analysis I. Standardization," TrAC, vol. 17, no. 5, pp. 289-298, 1998.

[32] H. Sandström, S. Reeder, A. Bartha et al., "Sample preparation and analysis," in Geochemical Atlas of Europe. Part 1-Background Information, Methodology, and Maps, R. Salminen et al., Ed., Geological Survey of Finland, Espoo, Finland, 1998.

[33] L. De Temmerman, L. Vanongeval, W. Boon, M. Hoenig, and M. Geypens, "Heavy metal content of arable soils in Northern Belgium," Water, Air, and Soil Pollution, vol. 148, no. 1-4, pp. 61-76, 2003.

[34] R. Webster, "Regression and functional relations," European Journal of Soil Science, vol. 48, no. 3, pp. 557-566, 1997.

[35] R. Webster, "Statistics to support soil research and their presentation," European Journal of Soil Science, vol. 52, no. 2, pp. 331-340, 2001.

[36] Z. Peh and S. Miko, "Geochemical comparison of stream and overbank sediments: a case study from the žumberak region, Croatia," Geologia Croatica, vol. 54, no. 1, pp. 119-130, 2001.

[37] G. M. Ivanov and V. K. Kashin, "Vanadium in the landscapes of western Transbaikalia," Geochemistry International, vol. 48, no. 3, pp. 295-299, 2010.

[38] A. J. Wigginton and D. J. Price, "Analysis of Metals in Water, Stream Sediments, and Floodplain Soils Collected May 2325, 2006 from the Bayou Creek System," DRAFT REPORT, February 2007.

[39] W. M. Mayes, A. P. Jarvis, I. T. Burke et al., "Dispersal and attenuation of trace contaminants downstream of the ajka bauxite residue (Red Mud) depository failure, Hungary," Environmental Science and Technology, vol. 45, no. 12, pp. 5147$5155,2011$. 
[40] L. R. Lado, T. Hengl, and H. I. Reuter, "Heavy metals in European soils: a geostatistical analysis of the FOREGS Geochemical database," Geoderma, vol. 148, no. 2, pp. 189 199, 2008.

[41] L. Horckmans, R. Swennen, J. Deckers, and R. Maquil, "Local background concentrations of trace elements in soils: a case study in the Grand Duchy of Luxembourg," Catena, vol. 59, no. 3, pp. 279-304, 2005.

[42] P. Tume, J. Bech, L. Tume et al., "Concentrations and distributions of $\mathrm{Ba}, \mathrm{Cr}, \mathrm{Sr}, \mathrm{V}, \mathrm{Al}$, and $\mathrm{Fe}$ in Torrelles soil profiles (Catalonia, Spain)," Journal of Geochemical Exploration, vol. 96, no. 2-3, pp. 94-105, 2008.

[43] D. J. Huisman, F. J. H. Vermeulen, J. Baker, A. Veldkamp, S. B. Kroonenberg, and G. T. Klaver, "A geological interpretation of heavy metal concentrations in soils and sediments in the southern Netherlands," Journal of Geochemical Exploration, vol. 59, no. 3, pp. 163-174, 1997.

[44] M. Aide, "Geochemical assessment of iron and vanadium relationships in oxic soil environments," Soil and Sediment Contamination, vol. 14, no. 5, pp. 403-416, 2005.

[45] S. R. Oliva and A. J. F. Espinosa, "Monitoring of heavy metals in topsoils, atmospheric particles and plant leaves to identify possible contamination sources," Microchemical Journal, vol. 86, no. 1, pp. 131-139, 2007.

[46] T. Sterckeman, F. Douay, D. Baize, H. Fourrier, N. Proix, and C. Schvartz, "Trace elements in soils developed in sedimentary materials from Northern France," Geoderma, vol. 136, no. 3-4, pp. 912-929, 2006.

[47] A. Naeem, P. Westerhoff, and S. Mustafa, "Vanadium removal by metal (hydr)oxide adsorbents," Water Research, vol. 41, no. 7, pp. 1596-1602, 2007.

[48] B. Wehrli and W. Stumm, "Vanadyl in natural waters: adsorption and hydrolysis promote oxygenation," Geochimica et Cosmochimica Acta, vol. 53, no. 1, pp. 69-77, 1989.

[49] VLAREBO, "Vlaams reglement betreffende de bodemsanering. Decree on Soil Remediation and Soil protection," ratified by the Flemish Government on October 2006.

[50] C. Carlon, M. Dalla Valle, and A. Marcomini, "Regression models to predict water-soil heavy metals partition coefficients in risk assessment studies," Environmental Pollution, vol. 127, no. 1, pp. 109-115, 2004.

[51] D. G. Schulze, "Separation and concentration of iron-containing phases," in Iron in Soils and Clay Minerals, J. W. Stucki, B. A. Goodman, and U. Schwertmann, Eds., pp. 63-81, Reidel, Dordrecht, The Netherlands, 1988.

[52] S. Covelli and G. Fontolan, "Application of a normalization procedure in determining regional geochemical baselines," Environmental Geology, vol. 30, no. 1-2, pp. 34-45, 1997.

[53] K. C. Schiff and S. B. Weisberg, "Iron as a reference element for determining trace metal enrichment in Southern California coastal shelf sediments," Marine Environmental Research, vol. 48, no. 2, pp. 161-176, 1999.

[54] V. J. G. Houba, T. M. Lexmond, I. Novozamsky, and J. J. Van Der Lee, "State of the art and future developments in soil analysis for bioavailability assessment," Science of the Total Environment, vol. 178, pp. 21-28, 1996.

[55] M. McBride, S. Sauvé, and W. Hendershot, "Solubility control of $\mathrm{Cu}, \mathrm{Zn}, \mathrm{Cd}$ and $\mathrm{Pb}$ in contaminated soils," European Journal of Soil Science, vol. 48, no. 2, pp. 337-346, 1997.

[56] S. Sauvé, W. Hendershot, and H. E. Allen, "Solid-solution partitioning of metals in contaminated soils: dependence on $\mathrm{pH}$, total metal burden, and organic matter," Environmental Science and Technology, vol. 34, no. 7, pp. 1125-1131, 2000.
[57] K. L. Mandiwana, N. Panichev, and R. Molatlhegi, "The leaching of $\mathrm{V}(\mathrm{V})$ with $\mathrm{PO}_{4}{ }^{3-}$ in the speciation analysis of soil," Analytica Chimica Acta, vol. 545, no. 2, pp. 239-243, 2005.

[58] W. P. Miller, D. C. Martens, L. W. Zelazny, and E. T. Kornegay, "Forms of solid phase copper in copper-enriched swine manure," Journal of Environmental Quality, vol. 15, no. 1, pp. 6972, 1986.

[59] O. K. Borggaard, "Selective extraction of amorphous iron oxides by EDTA from a Danish sandy loam," Journal of Soil Science, vol. 30, pp. 727-734, 1979.

[60] B. Nowack and L. Sigg, "Dissolution of Fe(III)(hydr) oxides by metal-EDTA complexes," Geochimica et Cosmochimica Acta, vol. 61, no. 5, pp. 951-963, 1997.

[61] H. E. Gäbler, K. Glüh, A. Bahr, and J. Utermann, "Quantification of vanadium adsorption by German soils," Journal of Geochemical Exploration, vol. 103, no. 1, pp. 37-44, 2009. 

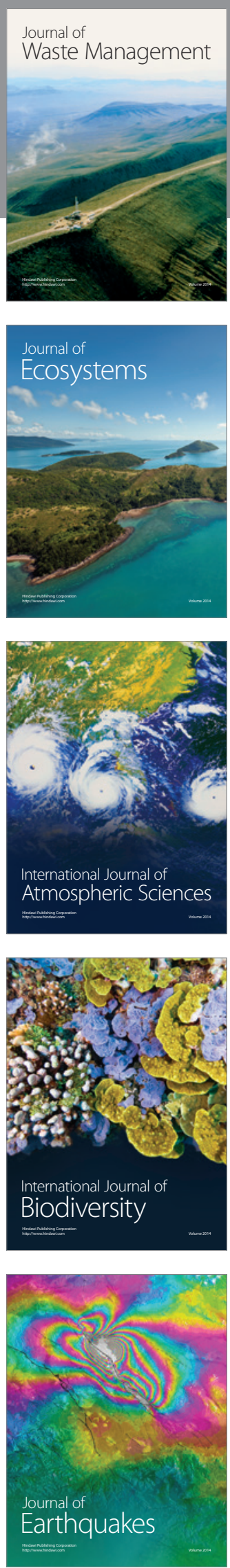
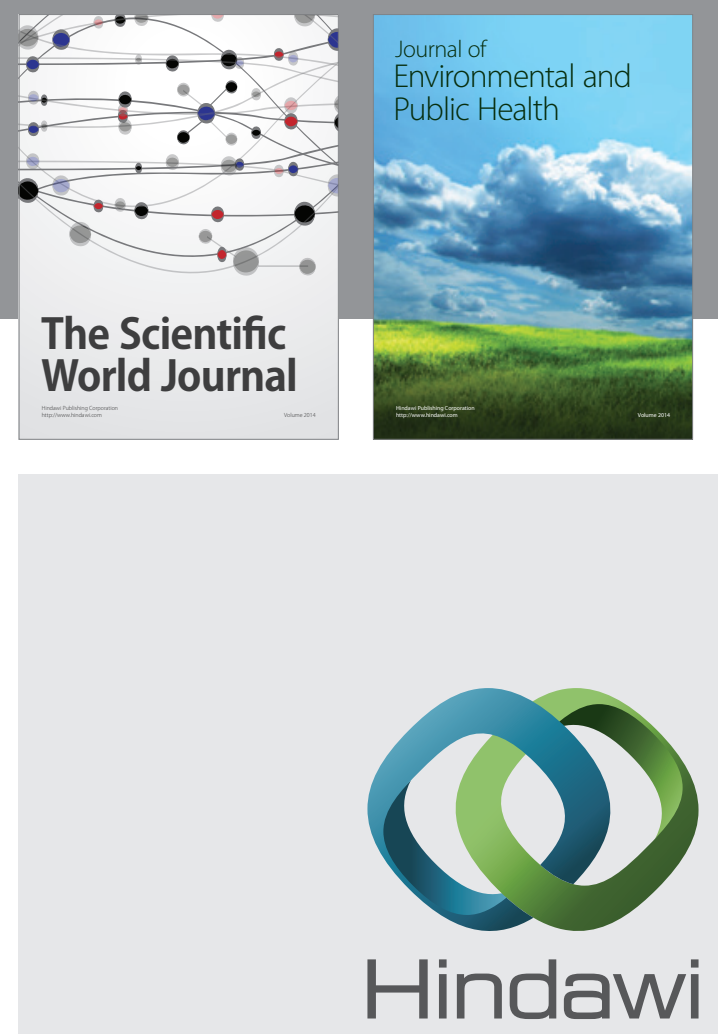

Submit your manuscripts at

http://www.hindawi.com
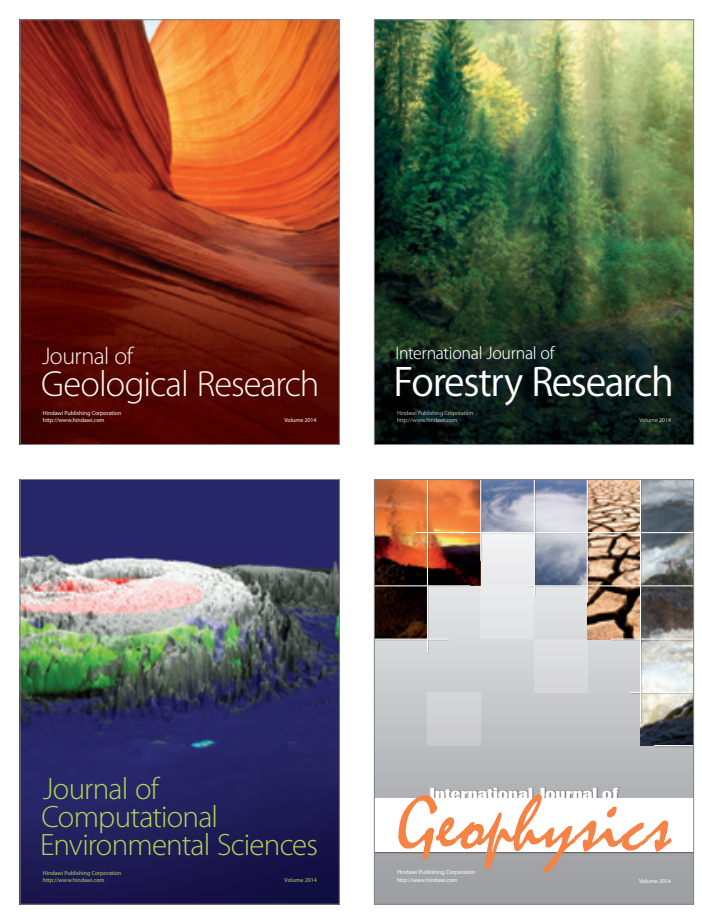
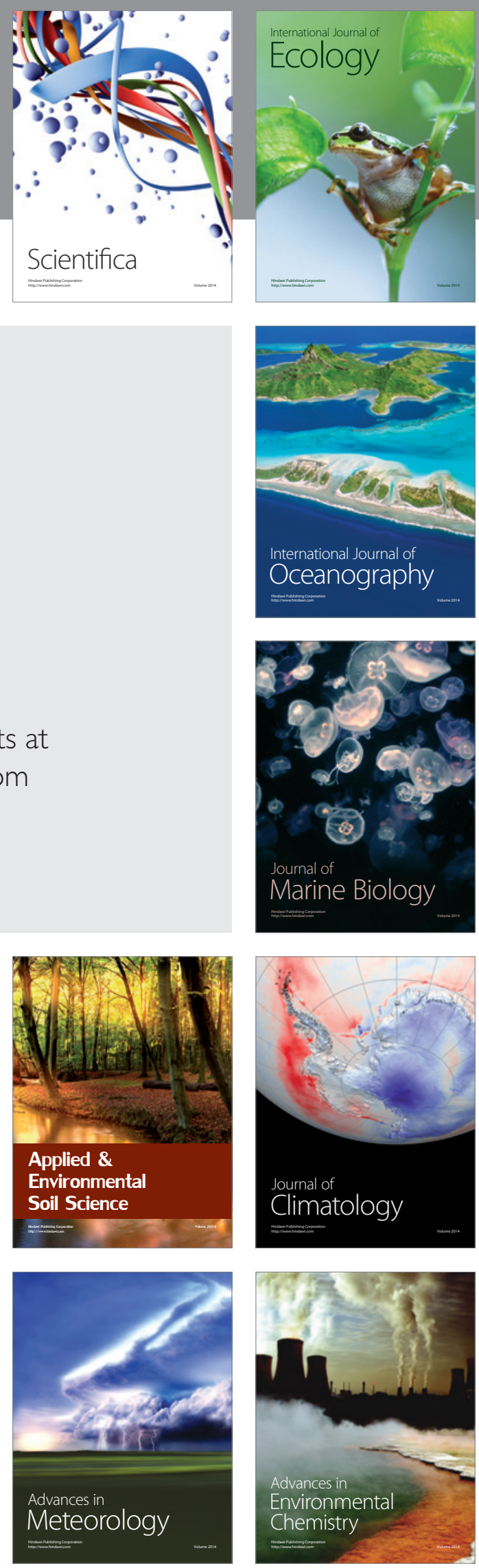